\title{
Religion and Politics - The Icelandic Experiment
}

\author{
PÉTUR PÉTURSSON \\ University of Iceland
}

\begin{abstract}
In a comment on Richard F. Tomasson's 1980 book about Iceland, the American sociologist Seymour Martin Lipset notes that Tomasson 'traces the ways in which Icelandic culture developed out of the medieval pre-Christian society - in its language, relations between the sexes, egalitarianism and the high frequency of illegitimate births. He also points out the areas of contradictions and discontinuity, noting that Iceland has been transformed in the twentieth century by modernization of the society and international influences upon the culture.' The purpose of this essay is to give a more in-depth analysis of some of Tomasson's observations with regard to the status and role of religion in this society. Iceland appears to be a very secular society, but up to very recent times, the national church had a strong position in Icelandic society, and its participation in the life-rituals of families, in national festivals, and in local rituals and festivities has been considered selfevident by the authorities and a large majority of the people. A very homogeneous culture and strong nationalism have a role here to play, but there were also seeds of individualism and pragmatism which may have led the way to differentiation and secularization. Secularization and modernization went hand in hand with the national liberation movement, but nevertheless the national church also made a major contribution to the nation-state building process. It would seem that the Icelanders have throughout their history been more political than religious - and often they seem to have been tolerant in religious and moral issues but fundamentalists in political matters. At least it seems profitable to analyse the religious history of Iceland - the conversion of Iceland at the Alpingi in the summer of 1000; the Reformation in the mid-16th century, and the rapid process of modernization in Iceland in the context of the political history. Foreigners have often wondered about the liberal attitude of Icelanders in relation to premarital sex, and often they ask why spiritualism and belief in elves and hidden people seem to have survived modernization and secularization. Other possible paradoxes include the very recent appearance of nonChristian religions, such as the Asa faith (which is supposed to revive the pre-Christian religion in Iceland), Islam and Buddhism. And how are we to understand the general support, even among the clergy, for same-sex marriages? In my essay I will try to contextualize these and related questions into an overall picture of the religious history of the Icelandic people.
\end{abstract}

Keywords: Iceland, history of religions, politics 
With a small and a homogenous population isolated on an island in the North Atlantic ocean, having kept records since the settlement period in the 9th century CE and stories and legends from that time and cultivating its own literature since the 12th century, Iceland certainly could be considered a laboratory case for historical, cultural and social research. In this essay I will try to do just that, focusing on religion referring to my own research (especially Pétursson 1990; Björnsson \& Pétursson 1990; Pétursson 2000; Pétursson 2011a) and others, using a bird's-eye view with the help of an American sociologist, Richard Tomasson, who stayed in Iceland in the 1960s and published his book: Iceland, the first New Society in 1980. He certainly grasped the idea of Iceland as an experiment for socio-cultural analysis. As a qualified sociologist he was invited by the University of Iceland to assist in founding the new Department of Social Sciences. He stayed long enough in Iceland to learn the language, become acquainted with Icelandic social scientists and some of the major intellectuals and literary people, and gather facts and figures. His book gives both a broad historical presentation, and a considerable insight into Icelandic culture.

In order to understand the religious evolution in Iceland we have to start with the Icelandic, or the Old Norse, literature. The Christian priest Ari the Wise (1067-1148) wrote the Book of the Settlement (Landnáma), and the Book of Icelanders (Íslendingabók), which is supposed to include a description of the Christianization of Iceland. The Sagas are more or less based on these books. At the same time as the Roman Catholic Church was becoming established in Iceland with its schools and monasteries, the old Norse literary culture was cultivated, adopting the Latin alphabet for writing legal texts, poems, annals, sagas, legends and religious literature of various kinds.

As Tomasson and others have noted, there is a striking continuity in the literary tradition of the country, which became a major source of identity in the nation-building process of the 19th and 20th centuries. That Iceland had its own distinctive language, literature and history was the main argument of the political leaders claiming independence vis-à-vis the Danish State. For the position of the Church, it was of crucial importance that her language was Icelandic, while the secular officials and the juridical system used Danish. The 'pure' Icelandic language was retained by the common people in rural areas, while officials and the Danish merchants and their representatives used Danish, or a very Danish-influenced Icelandic. To keep the language clean was one of the major objectives for the national liberation movement. Even today children can still read the Sagas; the heroes of the Sagas belong to their games, and they figure in modern literature, films and popular cul- 
ture. Most farmers around the island know about the first settlers of their locations, and some of them have opinions about the different characters and the controversial issues dealt with in the Sagas.

At the time of the Reformation in the middle of the 16th century, this literary activity had stagnated, but the Sagas lived on as a part of the popular culture. The Reformation brought a printing press to the country, and the Bible was printed in Icelandic in 1584. In the early 18th century, many of what was left of the old written manuscripts were transported to Copenhagen for conservation and research. The Danish state authorities had found it necessary to define their own origin and history against the world culture. Before the 19th century, only a few of the old texts had been printed for popular use, but a whole series of religious literature was printed in Icelandic by the Church in Iceland: hymnals, catechisms and sermons which nourished Christian life, which was mainly pursued in private homes, in the isolated individual farmsteads. In wintertime people would often not be able to attend church regularly on Sundays, but instead the practice of praying and reading psalms and sermons at home was established and was maintained in rural areas well into the beginning of the 20th century. Still today some 30 per cent of parents of young children pray with them before they go to sleep, and this tradition may be traced to the religious services in the farms at the evening vigil (kvöldvaka). (Trúarlíf Íslendinga 2004; Gíslason 1977.)

Up to the 20th century, Iceland was a backward and primitive society of farmers and officials, of which the clergy was the backbone. In 1805 the population of Iceland was about 46 000, including 210 clergy, 10 sheriffs with a legal education, 5 teachers at the only Latin school in the country, and 5 medical doctors. By 1900, the population had increased to 78000 but the clergy had fallen to about 140, whereas there were now 47 medical doctors. In 1930 the population was 106 000, including 100 clergymen and 120 medical doctors. (Pétursson 1990.)

Although the modern nation-building process started in the 1830s, Iceland was a latecomer in the process of modernization, by almost a century. Yet within a few decades, Iceland had become among the richest countries in the world, measured for instance by gross national production per capita. Due to the mechanization of the fishing industry and exploitation of geothermal power and waterfall resources, Icelanders were able to build a welfare society according to the Nordic model. By the 1960s, a high-quality health service and high standard of living had been realised. With this in mind, it is interesting to observe the religious profile of the Icelanders compared to other nations. 


\section{The First New Society - An Experiment}

As a complement to his historical analysis, Tomasson conducted his own survey of Icelanders' values, religion and worldview, based on interviews with a random sample of 100 Icelanders. As the title of his book suggests, he saw Iceland as the first new frontier society, colonized by Europeans in the wake of the Viking expansion westward from the 8th century. This, he felt, characterized the history, culture and the national character of the Icelanders, displaying some major similarities with his own nation, but nevertheless also some distinctive qualities, which he maintained might be traced all the way back to the origin of the native culture and society of this island. Comparing his own country, the USA, one of the biggest nation in the world, with one of the smallest, he writes:

I would argue that the 'American' value orientations are more dominant in Icelandic culture than in American Culture. This is true of achievement, equality, and nationalism-patriotism. Also, the value of external conformity is probably stronger in Icelandic culture than in American culture, and it is related to the value of equality [...] While Icelanders are clearly less nationalistic and patriotic (or rather, ethnocentric) than they were in the past, these traits are still more dominant in Icelandic culture than in America [...] (Tomasson 1980, 202.)

Tomasson relates this egalitarianism and nationalism-patriotism to the literary tradition. Thus he makes another most interesting, and, I find, relevant observation:

The Icelanders possess an extraordinary and unique historical and literary tradition that has bound them to their past and has continually replenished their culture. No European people can see its history with anything like the unity that the Icelanders see, with the partial exception of the Jews but they have had neither the geographical stability nor the cultural isolation of the Icelanders. Americans and the peoples of the other new nations have some of the same sort of national awareness, cultural mythology, and sense of continuity. But the Icelanders' extreme cultural homogeneity, their isolation, and their classical language and literature, combined with the smallness of their society, have intensified the intimacy Icelanders feel toward their national experience. For example, nearly all Icelanders could, if they wished, trace their lineages back to Bishop Jón Arason, the last Catholic bishop in Iceland, who died in 1550; he had nine illegitimate children. (Tomasson 1980, 18.) 
Tomasson argues that the literary tradition is of crucial importance for understanding the egalitarianism of the Icelanders. As mentioned above, the fact that Icelandic children can still read the Icelandic Sagas of the 13th and 14th centuries, and that ordinary people, as well as academic historians and literary experts, identify with the events described and the heroes of the Sagas, is unique for the Icelandic people. This creates manifold points of interest and contacts between on the one hand the 'high' and literary culture of the officials and the intelligentsia, and the common people and the folk culture on the other (Ibid. 203). People of different social and educational background know the accounts from the Book of the Settlement about the first settlers and their life stories, and it is not uncommon for some of them to get into literary disputes with university professors on issues related to the Sagas, for instance on who is the author of the Njáls Saga, one of the most famous of these texts.

Tomasson observed some interesting peculiarities of the culture and life values of the Icelanders. He characterises them as highly individualistic, yet at the same time family-oriented, especially emphasising the value of the extended family. This has also been substantiated by empirical research (Björnsson \& Pétursson 1990; Jónsson \& Pétursson 1994). Since the time of relevant statistics in the 19th century, there has been, compared to other Nordic countries, quite a high tolerance for girls to have their first child out of wedlock. Usually they could rely on support from the extended family, and very often the illegitimate child would become legitimate, as the parents would marry when they had established themselves.

In his doctoral study, The Lutheran Doctrine of Marriage in Modern Icelandic Society, Björn Björnsson maintains that the pre-Christian and Germanic betrothal institution lived on in Iceland in spite of the Church's many attempts to eliminate it or integrate it with the marriage ceremony (Björnsson 1971). Betrothal was a more or less secular institution, in which the families concerned agreed on the terms of the couple's engagement. This helps to explain for instance the high percentage of illegitimate children in Iceland in the 19th and the first half of the 20th century (ibid.). That the church had to put up with this is shown by the fact that it was common that the clergymen themselves had illegitimate children or their first child was obviously conceived before the marriage.

Björnsson made a survey on family types in the village of Akranes in the 1960s, and proposed a type of family in Iceland which he called the 'Engagement family', composed of the young parents of an illegitimate child, often living at the house of the parents of one of them until they had 
finished their education or established themselves socially and even built their own house. Often they would be married by the local pastor at the same time as their first child was baptized, which meant that it was registered at the same time as a legitimate child. (Björnsson 1971.)

Another major finding by Tomasson was that the Icelanders are highly materialistic, practical, and even secular, yet at the same time highly religious in their own way. The basic character of this religion, he suggests, is rationalism and tolerance. Dogmatism is not a characteristic of the religion of the Icelandic people, he maintains; that is reserved for their attitudes in political matters. Their practical and tolerant attitude in religious matters Tomasson and others trace firstly as far back as to the official conversion of Icelanders to Christianity at the Alpingi in its summer session in Pingvellir in the year 1000; secondly to the political character of the Reformation just before the middle of the 16th century, and thirdly to the fact that there was no religious revival in Iceland comparable to those in the neighbouring countries: the Nordic countries, Britain, and North America in the 18th and 19th centuries.

Table 1: Status of Firstborn Children born 1811-1931 to Icelandic Clergy. Percentages. (Source: Tomasson 1980, 95)

\begin{tabular}{|l|c|c|c|}
\hline Status of Children & $\mathbf{1 8 1 1 - 1 8 5 0}$ & $\mathbf{1 8 5 1 - 1 9 0 0}$ & $\mathbf{1 9 0 1 - 1 9 3 1}$ \\
\hline Born illegitimate & 18.0 & 15.6 & 10.5 \\
\hline $\begin{array}{l}\text { Born 0 to 8 months after father's } \\
\text { marriage }\end{array}$ & 24.7 & 16.1 & 30.5 \\
\hline $\begin{array}{l}\text { Born 9 or more months after father's } \\
\text { marriage }\end{array}$ & 57.3 & 68.3 & 59.0 \\
\hline Total & 100 & 100 & 100 \\
\hline Number of Clergy with children & 89 & 180 & 95 \\
\hline Number of Clergy without children & 18 & 40 & 36 \\
\hline
\end{tabular}




\section{The Conversion of Iceland to Christianity}

It may be argued that Icelanders were both syncretic and individualistic in religious matters during their first period of the settlement in the newly inhabited island. Free from their previous local traditions in legal and religious matters, many of the settlers came to Iceland from areas dominated by the traditional pre-Christian, 'heathen', religion. Not a few of the chieftains, however, had spent shorter or longer periods of time in Christian Ireland . New DNA research on the blood type of present-day Icelanders suggests that about 63 per cent of the women among the first settlers, and about 20 per cent of the males, were originally Gaelic (Helgason 2000; 2001). The others are assumed to have originated from Norway. It thus seems to have been a common practice for Norse men to take with them women and slaves from Ireland. These people found a way to live together and to establish their own local juridical institutions (the ping), and in 930 a single legislative and judiciary body, the Alpingi, at Pingvellir in the South-West of Iceland, by some considered to be the first relatively democratic parliament (though in fact an oligarchy).

Although Ari the Wise, writing for the bishops and the ruling families, mentions in the Book of the Settlement that the first humans living in Iceland were Irish hermits, historians and literary researchers have emphasized the Norwegian background of the first generation of settlers. Ari the Wise states that these monks later left the island, and that the population became more heathen towards the end of the Millennium. This of course made the efforts of the missionary King Olafur Tryggvason look more impressive and glorious, exercising his political influence on the Icelandic chieftains to push the Icelanders to adopt Christianity. The King's mission represented the more institutionalized form of Christianity, with its centre in Rome, which did not recognize the Irish-tradition Christians living in the country as members of the Church. Some scholars have also suggested that the Irish monks did not in fact disappear, but may have stayed and mingled with the population, serving them in different ways and helping to bring up and educate some of the young men.

The story in Íslendingabók about the conversion of Iceland to Christianity has a legendary flavour to it. The concessions that were made suggest the political character of this baptism of the entire population. The leader of the Christian group, Síðu-Hallur, had negotiated with the Speaker of the Alping, Porgeir ljósvetningagoði, 'still a heathen' as it says, to reach the decision whether Iceland should be Christian or not. After taking his time to meditate about the options, he decided everybody should be Christian, but with some important concessions to the old practices. (Aðalsteinsson 
1999.) According to Ari the Wise in the Íslendingabók, people could still eat horse meat and put infants into the wilderness to die, and even pay tribute to the old gods, if nobody could bear witness to it in court. The annals say, however, that these practices were soon totally abandoned because of the respect that the people had for their bishops.

This suggests that the conversion of Iceland to Christianity was a process that took at least two centuries, and that there was a pluralistic situation in religious matters before the Christian church finally and completely established itself in the 12th century. We can surmise that there existed a kind of a civil religion which made it possible for both Christians and heathens to live together and solve administrative tasks and legal issues at the local assemblies (ping) and at the central legislative and juridical assembly the Alpingi. This somewhat syncretic milieu, the best witness to which is the most famous Nordic mediaeval Eddic poem Völuspá, provided a rich breeding ground for the flourishing Icelandic literature from the 12th century. Some researchers think that this poem, which incorporates both heathen and Christian themes, may be traced back to the period before 1000, while others see it as a product of the 12th century (Pétursson 2013). The Christian culture would nevertheless be both an inspiration to and a part of the Icelandic literary heritage that was to be crucial for the formation of the national identity. It can also be stated that the social framework of the church soon became closely integrated with the infrastructure of the society.

\section{Reformation, Pietism and the Danish King}

The two bishoprics with their schools, and the Alpingi at Pingvellir, were the basic cultural and social institutions of the country until the turn of the 18th century. For most of that period, Iceland belonged to the archdiocese of Niðarós in Norway; in 1262 Icelanders had fallen under the rule of the Norwegian King, and in 1387 under the King of Denmark.

The Reformation came about in Iceland for much the same political reason as elsewhere, namely because of the interest of the territorial rulers to free themselves of the rule of Rome. Some young Icelanders had become influenced early on by the ideas of the Reformation, but it was the emissaries of the Danish King pressing for the introduction of the Lutheran order in Iceland which meant that the Danish King could claim the landed property of the monasteries. In the diocese of Skálholt, the Lutheran order was introduced in 1541, and ten years later in the Northern diocese of Hólar. The Bishop of Hólar, Jón Arason, was a strong leader and opposed the Danish interests; he 
was executed in 1550, becoming something of a national hero. Even if the Danish King was nominally accepted in 1662 as absolute ruler in Iceland the bishops remained strong leaders in the country. (Porláksson 2003.)

The trade monopoly administered by the royal officials, and rationalization of the royal administration, together with natural hardship and disasters, meant economic deterioration and diminished initiative of the local people in social matters in the 17th and 18 centuries, and it was not until after the middle of the 19th century that some major social improvements began to take place.

In the first half of the 18th century the Royal Court in Copenhagen was influenced by the conservative branch of pietism. which inspired some reforms in education and church matters on Iceland. Concerned about the status of Christian beliefs and practices in Iceland, the Royal Administration sent an emissary to Iceland, Pastor Ludvig Harboe, to carry out a survey of the religious and moral situation of the Icelanders. He travelled around Iceland in 1741-5, investigating questions such as the educational standard of the local clergy and the reading skills and Christian knowledge of young people. He found them lacking in several respects, and his recommendations to the administration resulted in new regulation on the catechism and the education of young people. Local pastors were put in charge of the inspection of education and Christian morality, and consequently they became major agents of social control. They were obliged to make regular inspections in all homes in their parishes, and to keep records on the moral, religious and the educational standard in every home. (Guttormsson 1983.) In consequence, even though were practically no schools in the country except the Latin schools, by the turn of the 18th century illiteracy had been practically abolished, since the clergy would be fined if they confirmed a child who could not read the catechism (Ibid.).

When people started to move to the fishing villages in the late 19th century, the local pastors could no longer themselves function as the teachers of the young generation, and therefore hired ambulatory teachers who travelled between the local farms; and towards the end of the 19th century, more and more clergy set up children's schools in their parishes. (Pétursson 1990, 61-7.)

\section{Poor People under Foreign Rule}

Social control over the local people by the clergy was of course a part of the policy of the royal administration to get a hold on this peripheral popula- 
tion in the far away colony. The royal officials in Copenhagen governing all church matters treated the Icelandic church as a more or less obedient instrument of its administrative apparatus. Another part of their program was the privileges that Icelandic student had as university students in Copenhagen. The plan was to breed loyal servants of the Danish administration. At the end of the 18th century, the termination of the Alpingi at Pingvellir, and the replacement of the old bishoprics and cathedral schools at Hólar and Skálholt by a single bishop and one Latin school for the whole country situated under the Royal Governor in Reykjavík, further tightened the grip of the Danish administration over all official aspects of life in Iceland.

During the 18th century, natural hardships, the depressed economy, and a lack of local initiative resulted in the population dropping below 50000 . By the 19th century, there was little left of the proud medieval culture and the prosperous society of Iceland. The Royal officials in Copenhagen had difficulties in understanding the situation in Iceland. Few means to work for the betterment of the economic and cultural situation seemed at hand in the country. Experiments with industries in Iceland in the 18th century had failed completely, and the interest of the landowners in keeping cheap labour in the countryside prevented the development of the prosperous fishing industry in the coastal villages. (Gunnarsson 1983.) Indeed there was no Icelandic bourgeoisie or middle class in the modern sense until the 20th century. The relatively prosperous commercial companies were in the hands of Danish-based merchants, and most of the profit went there. The Icelandic population was composed of farmers and rural servants and officials. Moreover, the initiatives for political and social improvements also came from Copenhagen, grounded in the literary activities of the Icelandic students and intellectuals based there who were inspired by their mediaeval ancestors' literary production and the new political ideas in Denmark, Germany and France. In general one can say that during the $19^{\text {th }}$ century the Icelandic clergy became agents of the national liberation process, where they had previously been agents of the status quo under the Royal Administration. (Pétursson 1990.)

\section{A Country without a Religious Revival}

The University of Copenhagen and some literary societies for the research and publication of the old Nordic literature made it possible for some Icelandic intellectuals to support themselves there. Together with the Icelandic university students they came to compose a national elite concerned with 
Icelandic matters and ideas for the improvement of the economic and cultural situation in their home country.

In the 1830s these intellectuals, who had been following the cultural and political development in Europe, became increasingly politicized, demanding more political rights for their countrymen and putting pressure on the Danish authorities in the name of national rights, democracy and civil rights. In mobilizing the local population in Iceland, they could rely not only on their friends, former schoolmates and family members, but also on the local pastors, who were as mentioned above in close contact with the local farming people (Pétursson 1990, 91-5). Since the clergy at least partly supported themselves as farmers, they were also able to represent the interests of the farming people themselves. They were often elected as members of the Alpingi, the parliament re-established in Reykjavík in 1845, and they were in the forefront of those who gradually mobilized various initiatives for the betterment of the cultural and social situation in the local communities, be it through commercial or cooperative organization, literary societies, or organizations for the spread of abstinence. Neither the Icelandic intellectuals in Copenhagen nor the Icelandic clergy were interested in the great contemporary debates about religious and theological issues in Denmark, and they avoided these issues in their periodical and in the publications they wrote and sent home to their countrymen to inspire them and to awaken their social and political awareness. These theological issues were considered as totally irrelevant for the only important cause, which was to unite the Icelandic people for increased national and political rights. The basic theme of these political writings was the maintenance of the literary tradition and to integrate it with the new ideas of political liberation flourishing in Europe. (Pétursson 1990, 87-91.)

When the King of Denmark renounced Royal absolutism in 1848, and opened up for democratization of the government and parliamentary reforms, the Icelanders in Copenhagen immediately saw this as an opportunity to increase the political rights of their country. They opposed the suggestion to have Icelandic members of the all-Danish Assembly (Riksdag); they wanted their own parliament, the Alpingi, to have legislative authority, and to have executive decision makers not dependent on Danish ministers but serving directly under the Danish King. The King promised Iceland its own constitutional assembly, but for various reasons it was delayed until the summer of 1851. By then, more conservative movements had regained ground in Europe and Denmark, and the Governor General (Stiftsamtmaður) representing the King and the Danish Administration denounced a proposal 
of the majority of the Alpingi members, led by Jón Sigurðsson (1811-1879), to establish the Alpingi as an independent legislative body. (Karlsson 2008a.) When the Governor General dissolved the session, Jón Sigurðsson and his group protested in the name of the King and the Nation. This caused a stalemate in Danish-Icelandic political relations. Jón Sigurðsson and his group did not want to negotiate about Icelandic national rights with officials of the Danish Administration legitimized by the Danish Parliament; referring to the old agreements between the Icelanders and the Norwegian King from the 13th century, Sigurðsson wanted to negotiate directly with the sovereign monarch about the position of Iceland within the Danish State (Ibid.).

The aftermath of the 1851 events showed that the local clergy were by and large more independent from the Royal Administration than other officials, since they did not receive their salaries from the State Fund but from the local parishioners and from the landed property of the Church itself. While other pro-Icelandic officials lost their offices, the parish pastors supporting Jón Sigurðsson could not be penalized (Pétursson 1990, 98-101). Up to 1920 the clergy often would make up a quarter of the members of the Alpingi. In the 1920s, however, this fell to about 7 per cent (Pétursson 1990, 101), and in the latter half of the 20th century there were periods when there was no representative of the clergy in the Alpingi at all.

The political stalemate in Icelandic-Danish relations lasted until 1874. when at the official celebration of the Icelandic national millennium the King handed over a new Constitution for Iceland granting the Alpingi legislative authority in what was described as internal matters of Iceland. At the same time religious freedom was instituted in Iceland. The Danish government was still the highest authority in Icelandic matters and had to endorse all proposals from the Alpingi. Parliamentarian government was instituted in 1904, when the position was created for a Minister for Icelandic Affairs situated in Reykjavík and responsible for his decisions to a majority in the Alpingi. As a member of the Danish Council of State, the Minister for Icelandic Affairs had nevertheless to present the decisions of the Alpingi to the King.

In the Constitution of 1874, the Evangelical Lutheran Church was defined as the National Church of Iceland. In 1904, it was officially differentiated from the state administration in Iceland and the Bishop of Iceland ceased to be a member of the highest Ruling Council (Stiftsyfirvöld) of the country. In 1918, Iceland then became an independent state in Royal union with Denmark, which meant that the Minister for Icelandic Affairs was no longer a member of the Danish Council of State. (Karlsson 2008b.) 


\section{Modernization and Liberal National Church}

As the turn of the 19th century approached, harsh critical voices were raised against the National Church and the religious situation in Iceland. The church was in bad need for reform and revival. Its then still continuing close relation to the Danish state administration was criticized by many, not least by the ardent nationalists, who wanted the separation of the Icelandic church from the Danish state. This led to the foundation of some Free Evangelical Lutheran Congregations, which maintained the same confessions and rituals as the National Church. The motive for the foundation of these Free Churches was mainly nationalist, though in some cases there was also dissatisfaction with the appointment of pastors: those whose candidate had not been appointed would leave the National Church and found their own congregation. (Pétursson 1990, 131-41.)

Secularist and atheist voices were also raised among intellectuals, inspired by the anti-church ideas of the radical Realism movement in Denmark (Guðmundsson 1996, 769-91). For some of the more ardent secularizers, however, psychic research and spiritualism seemed to offer a new approach to the Christian message, and were considered to provide empirical proof of the miracles in the Bible and of life after death (Pétursson 2011, 224-6).

The official Icelandic Church seems not to have the means to respond to this situation or to build up a platform against the anti-church propaganda. Just around the turn of the century - in relation to the work on a new translation of the Bible - some of the leading theologians argued for the historical and literary criticism of Bible texts and the liberal theology that had been flourishing in German universities in the latter half of the 19th century. These theologians saw the Lutheran church confessions as outdated and contrary to a modern view of life; some even denied that the clergy were bound to them, since the Lutheran confessions had never been presented or approved by the Alpingi. Some liberal theologians were also inspired by more liberal forms of Christianity in Britain and North America. (Pétursson 2007.)

Within a single decade, religious liberalism established a stronghold with the Church, and this was well received by intellectuals and the new bourgeoisie, inspired by a new hope for progress and greater prosperity. Together with an increasing interest among artistic and literary circles in symbolism and the esoteric, this mitigated secularism and atheism among those who valued freedom and individualism and wanted to leave past oppression and poor conditions behind. It seems as if this liberal theology, 
with its nationalism and its tolerant attitude towards popular religious developments such as spiritualism and theosophy, became somewhat like a Liberation Theology for the new Icelandic bourgeoisie and middle class during the first half of the 20th century, as they established their own interests and cultural identity vis-à-vis the Danish interests. (Pétursson 1990, 190-5.) This development strengthened the position of the Evangelical Lutheran National Church, notwithstanding a more conservative wing based in the YMCA and YWCA, which was highly critical of liberal theology and especially of some liberal theologians leaning towards esoteric ideas and spiritualism (Pétursson 1981).

\section{The Icelandic Type of Christianity}

A leading figure in establishing this national and liberal Folk Church model was Bishop Pórhallur Bjarnarson (in office 1909-16). He was one of the most influential members of the Alpingi, and in close contact with the first Minister of Iceland, Hannes Hafstein. Previously he had served for many years as President of the Theological Seminary in Reykjavík, and as assistant to the Bishop of Iceland. He came into office when the separation process between church and state was just beginning; he emphasized democratic and national values, and maintained that the Lutheran confessions were not in line with the spirit of the age. This program was backed up by the Theological Faculty of the University founded in 1911, as all three professors were from the liberal theological school. (Pétursson 1996.)

He and his family supported the National Youth Movement which was the backbone of the Farmers Party (alias the Progressive Party) founded in 1916. The clergy associated with this church policy supported the national movement, leading to the final dissolution of the constitutional link with Denmark by the declaration of Iceland as a republic on 17th June 1944. By emphasising the social commitment of the clergy, this program provided legitimation for the church as a National Church and her political and cultural privileges.

For many years Bishop Bjarnarson was the chief spokesman for an independent Church Assembly, and his first Synods (clergy meetings for official affairs), which he symbolically held at Pingvellir, had the character of a general meeting about necessary reforms of the church and included some lay participation. He wanted to re-establish the old bishoprics at Hólar and Skálholt, and had two suffragan bishops ordained - partly to make the Icelandic church independent from the Danish state (ibid.). 
An independent Church Assembly was partly realized in 1957 when it became an advisory body to the Parliament in Church matters. In 1997 a further step towards separation was taken when the church formally handed over her landed property to the state, which then by contract would pay the salaries of the clergy. At the same time the legislative power in church matters was transferred to the Church Assembly, and executive authority from the Ministry of Church Affairs to the Bishop's Office. The Evangelical Lutheran Church of Iceland was therefore not supposed to be a state church any more but an independent religious body - though still a national church. (Pétursson 2000.)

In his book, Catechism and Church (Kver og kirkja) published in 1925, Ásgeir Ásgeirsson, a theologian and son in law of Bishop Pórhallur Bjarnarson, defined what he saw as the characteristics of Christianity in Iceland, which he argued were more in line with the spirit of Jesus Christ than the Christianity preached and practised in Denmark. Firstly, the absence of dogmatism and excessive religious revivals and revolutions that made Icelandic Christianity more mature than Danish religious life. Dogmatism he found to be contrary to the original message of Christ, and he characterized the religious revivals in Denmark (Grundtvigianism and the Home Mission) as expressions of an immature religious attitude, lacking in the calm and mature trust of personal faith. This mature attitude he found to be expressed in Iceland in the widespread practice of home services, prayers and sermon readings, notably the appreciation of the Passion Hymns of Rev. Hallgrímur Pétursson and the Book of Sermons by Bishop Jón Vídalín (Vídalínspostilla). Both texts were to be revered for their literary and psychological qualities, which Ásgeirsson saw as more important than orthodox Christian dogmas. This 'mature' kind of Christianity in Iceland was also expressed in the charity and social solidarity of the rural people throughout the ages. (Ásgeirsson 1925.)

Ásgeirsson stresses the importance of the literary tradition for the attitudes of the Icelanders towards religion. The more dignified values of heathendom lived on in Iceland, he maintains, and these were an inspiration for the literary tradition (Ásgeirsson 1925, 108). The popularity of the Sagas prevented Icelanders from clericalism and narrow-mindedness in religious issues - the Eddas, the Sagas and the materials of Nordic legend were closer to the 'national character' of the Icelanders than stories of the jealous God of the Old Testament, and this inspired the religiosity of the Icelanders with rationality and common sense (ibid. 98). Ásgeirsson stresses the importance of the narrative character of the literary tradition, which prevents Icelanders from excess and irrationality in matters of religion. Instead 
of religious conversions or revolutions on emotional grounds, Icelanders reason about religious matters - therefore their religion is more reasonable and rational than the Danish, who he saw as influenced by dogmatism and urban religious revivals.

Ásgeirsson also understands the Icelanders' interest in the paranormal phenomena of spiritualism and psychic research, dreams and folk religion to be an indication of sound and reasonable attitudes in matters of religion. These phenomena, he argues, are basic to the religious life in general, and witness to an independent and personal approach to religious matters closer to the New Testament witness of primitive Christianity than the rationality and dogmas of later scholastic presentation of the Good Message - that is, closer to the Gospel than to the law. Here Ásgeirsson is in line with his teacher at the Department of Theology at the University of Iceland, Haraldur Níelsson (1868-1928), a charismatic religious leader famous for his sermons and his new translation of the Old Testament, published in 1908. (Pétursson 2011b.)

\section{Religion, Pluralism and Tolerance}

When Iceland became a separate state in 1918, the social and political standing of the National Church was strong. The emergence of pluralism in religious matters, and harsh critique from anti-Christian groups, were phenomena of the late 20th century.

Surveys on religious beliefs and practices have been conducted since the 1980s, and they show that at least in comparison with other Nordic countries, a relatively high percentage of people believe in God, pray to God, and identify with the Christian message (Pétursson 2005). When asked if they get consolation and strength from their religion, a surprisingly high percentage of the Icelandic people say Yes. National surveys on religious beliefs and practices in 1987 and 2004 indicate that those who accept Christian beliefs are not a diminishing group, but that there has been a polarization about religious issues: the category who disassociate themselves from the Christian church and Christian beliefs has grown, but the big middle group that is lukewarm has diminished (Trúarlíf Îslendinga 2004).

The Roman Catholic Church in Iceland is mainly composed of immigrants, as is the case with Muslims and most members of the Buddhist groups. In 1996 the Bishop of the National Church Ólafur Skúlason was accused by some women for sexual harassment (Pétursson 2000). These accusations got much mass media attention, and the Bishop had to resign 
Table 2: Religious affiliation registered by the state, percentage of the population.

\begin{tabular}{|c|c|c|c|c|}
\hline & 1960 & 1980 & 2000 & 2013 \\
\hline Lutheran National Church & 91.6 & 93.2 & 88.7 & 76.2 \\
\hline Lutheran Free Churches & 6.1 & 3.8 & 3.9 & 5.9 \\
\hline Roman Catholics & 0.5 & 0.7 & 1.4 & 3.4 \\
\hline Pentecostals & 0.3 & 0.3 & 1.0 & 1.1 \\
\hline Eastern Orthodox & & & & 0.3 \\
\hline Other Christian bodies & 0.4 & 0.4 & 0.6 & 0.6 \\
\hline $\begin{array}{l}\text { Asa-faith believers } \\
\text { (neo-pagans) }\end{array}$ & & & 0.1 & 0.7 \\
\hline Buddhist groups & & & 0.2 & 0.3 \\
\hline Muslims & & & 0.1 & 0.2 \\
\hline Other religious bodies & & & 0.4 & 1.8 \\
\hline $\begin{array}{l}\text { Unaffiliated to any } \\
\text { religious bodies }\end{array}$ & 1.1 & 1.2 & 2.3 & 5.2 \\
\hline Total population & 175680 & 228794 & 279049 & 321857 \\
\hline
\end{tabular}

in the following year. This case continued to cause problems for the church, because the next Bishop, Karl Sigurbjörnsson, was accused of handling the issue improperly. A small but active group of Non-Believers (Vantrú) was founded in 2004, many of whom were members of the Society for Secular Humanism founded in 1990. They were very critical of the church leadership, and actively tried to get people to leave the Church. Some statements by the Bishop against atheists and secular humanism and against homosexual partnerships aroused public disapproval, and made some people leave the church, some of them moving to the Evangelical Lutheran Churches, and some not then joining any religious body. In 2012 the Bishop resigned, and the new Bishop elected was a woman. 
In his study, Tomasson found Icelanders extremely homogeneous in cultural and religious matters, and naively suspicious towards strangers and some deviant groups such as homosexuals, but this changed towards the end of the 20th century. In 2010, the Icelandic Parliament passed a Marriage Act which included same-sex couples, with strong support from among the clergy, including the new Bishop, Agnes Sigurðardóttir. One of the first to be married under the new Act was the then Prime Minister, Jóhanna Sigurðardóttir, and her partner Jónína Leósdóttir. Today Icelanders are becoming used to meeting black and yellow people who speak Icelandic fluently. The Russian Orthodox Church in Iceland, the Muslim Society and the Neo-Pagan Asa-Faith Society are all in the midst of building projects for a new church, mosque and temple.

The new legislation on the National Church in 1997 mentioned above meant yet further differentiation between the State and the National Church, and over the following years this process was extended by some further measures. The Ministry of Juridical and Church Affairs was renamed the Ministry of Juridical and Human Rights. In 2012 non-religious bodies concerned with secular beliefs or worldviews, such as the Secular Humanists, could register on comparable terms with religious organizations, which meant that they could claim the religious tax collected by the State and distributed to registered 'religious' bodies. The financial crisis of 2008 caused widespread distrust among the Icelandic people against the political authorities and some basic social institutions such as the Alpingi, the banks, the Financial Inspectorate and even the National Church. This led to a popular interest in reviewing the Constitution, and in 2012 a referendum was held where one of the question asked was whether the National Church should be addressed in the Constitution. 57 per cent of the voters supported the position that the Constitution should include an article about the National Church. This came as a surprise to many, because surveys conducted by Gallup since the early 1990s had consistently showed that following the principle of equality in religious matters, just over half of the Icelandic population favoured the total separation of church and state (Trúarlíf Íslendinga 2004). The Bishop and most church people interpreted the referendum result as support for the article in the Constitution stating that the Evangelical Lutheran Church is the National Church and is to be protected and supported by the State. 


\section{Concluding Remarks}

In his book, Iceland the First New Society, the American sociologist Richard Tomasson presents an interesting survey of the Icelandic history from its origin to modern time, and identifies some basic values and traits of the national character, tracing them as far back as to the formation of the society and culture and the composition of the Sagas. In this respect the national culture is interwoven by three strands: the political, the literary and the religious. Throughout its eleven centuries' history, different configurations of the cultural matrix have been dominant, but Tomasson stresses that some identifiable features have been maintained. These, he finds, are secular strands related to the literary tradition that has formed the backbone of national identity perhaps more than the official religion. In this essay I have addressed some of Tomasson's observations, and tried to broaden their scope of analysis with some new sociological and historical observations. An isolated and homogeneous society survives by being practical and reasonable in matters of morality and religion but dogmatic in political matters. Icelanders use the old Sagas to identify themselves and their boundaries against the outer world. At the same time they use this same literary tradition as a means to relate to the outer world and convince others of their unique role among the nations of the world. In order to do so, neither they nor their religion can succumb to foreign authorities. Their island has to be the centre of their world. This can both be an asset, as can be seen in the national movement for political independence in the 19th and 20th centuries; but it can also have fatal consequences, as was shown when a large group of Icelandic immigrants to North America in the late 1870s bypassed the rich farming land where they could have worked as farmhands for more experienced farmers, only to end up founding their independent New Iceland in barely inhabitable land at Lake Winnipeg in Manitoba (Friðriksson 2007). The fatal consequences of this nationalism also underlay the adventurous entrepreneurial projects that led to the financial crash in 2008.

In modern times, the official Christian religion in Iceland constitutes more of a framework and a platform than the essence of the culture. The narrative culture of the literary tradition is both individualistic and syncretic in its expression of the ultimate questions of life, and finds its way through the official religion; and this perhaps has made a liberal and a tolerant National Church survive in a modern and postmodern society. 
Bibliography

\section{Aðalsteinsson, Jón Hnefill}

1999 Under the Cloak, a Pagan ritual turning point in the conversion of Icelanders. Reykjavík: Háskólaútgáfan.

\section{Ásgeirsson, Ásgeir}

1925 Kver og kirkja. Reykjavík: Ísafold.

\section{Björnsson, Björn}

1971 The Lutheran Doctrine of Marriage in Modern Icelandic Society. Oslo: Universitetsforlaget.

\section{Björnsson, Björn \& Pétur Pétursson}

1990 Trúarlíf Íslendinga. Félagsfræðileg könnun - Ritröð Guðfræðistofnunnar 3.

Friðriksson, Bragi

2007 Fórnfús frumherji: Séra Páll Porláksson prestur Íslendinga í Vesturheimi. Garðabær: Garðasókn.

\section{Gíslason, Magnús}

1977 Kvällsvaka. Uppsala: Studia Ethnologica Upsaliensia 2.

Guðmundsson, Halldór (ed.)

1996 Íslensk bókmenntasaga III. Reykjavík: Mál og menning.

\section{Gunnarsson, Gísli}

1983 Monopoly Trade and Economic Stagnation: Studies in the Foreign Trade of Iceland, 1602-1787. Lund: Ekonomisk-historiska föreningen 38.

\section{Guttormsson, Loftur}

1983 Bernska, ungdómur og uppeldi á einveldisöld. Reykjavík: Ritsafn Sagnfræðistofnunar 10.

\section{Helgason, Agnar et al.}

2000 Estimating Scandinavian and Gaelic Ancestry in the Male Settlers of Iceland - American Journal of Human Genetics 67 (3) , 697-717.

2001 DNA and the Islands of the North Atlantic: Estimating the Proportions of Norse and Gaelic Ancestry - American Journal of Human Genetics 68 (2001), 723-37.

\section{Jónsson, Friðrik H. \& Pétur Pétursson}

1994 Religion and Family Values: Attitudes of Modern Icelanders in a Comparative Perspective - Torleif Pettersson and Ole Riis (eds), Scandinavian Values. Religion and Morality in the Nordic Countries. Uppsala: Acta Universitatis Upsaliensis. 151-67. 


\section{Karlsson, Gunnar}

2008a Upphaf pjóðríkismyndinar 1830-1874 - Sigurður Lindal (ed.), Saga Íslands IX, 271-9. Reykjavík: Hið íslenska Biblíufélag.

2008b Atvinnubylting og pjóðríkismyndun - Sigurður Lindal (ed.), Saga Íslands IX, 219-301. Reykjavík: Hið íslenska Biblíufélag.

\section{Pétursson, Pétur}

1981 Trúarlegar hreyfingar í Reykjavík tvo fyrstu áratugi 20. Aldar - Saga XIX, 177-273.

1985 Island - Göran Gustafsson (ed.), Religiös förändring i Norden 1930-1980, 111-95. Malmö: Liber förlag.

1990 Church and Social Change: A Study of the Secularization Process in Iceland 1830-1830. Reykjavík: Háskólaútgáfan.

2000 Pjóðkirkja, frelsi og fjölbreyttni - Hjalti Hugason (ed.), Kristnisaga Íslands IV, 199-440. Reykjavík: Alpingi.

2005 Fyrir og eftir 2000. Félagsfræðilegar kannanir á trúarlífi Íslendinga - Úlfar Hauksson (ed.), Rannsóknir í félagsvísindum VI. Reykjavík: Félagsvísindastofnun Háskóla Íslands. 123-37.

2007 Sekulariseringen, nationlismen och den liberala folkkyrkan på Island - Carsten Bach-Nielsen et al. (eds), Kirken Mellem Magterne. Artikler tilegnet Jens Holger Schörring, 207-25. Köbenhavn: Forlaget Anis.

2009 Pjóðin og pjóðkirkjan - Gunnar Kristjánsson og Skúli S. Ólafsson (eds.), Pjóðkirkjan og lýðræðið, 27-40. Reykjavik: Kjalarnessprófastsdæmi.

2011a Religion and State in Iceland - Nordic Journal of Religion and Society 24 (2), 189-204.

2011b Trúmaður á tímamótum. Ævisaga Haralds Níelssonar. Reykjavík: Hið íslenska bókmenntafélag.

2013 Manifest and Latent Biblical Themes in Völuspá - Annette Lassen and Terry Gunnell (eds), The Nordic Apocalypse, 185-205. Turnhout: Brepols Publishers.

\section{Tomasson, Richard F.}

1980 Iceland, The First New Society. Reykjajvík: Icelandic Review. Also: Minneapolis: University of Minnesota Press.

\section{Trúarlíf Íslendinga}

2004 Viðhorfsrannsókn, Reykjavík: Gallup.

\section{Porláksson, Helgi}

2003 Tekjur konungs - Sigurður Lindal (ed.), Saga Íslands VI, 99-107. Reykjavík: Hið íslenska Bókmenntafélag. 
